Agricultural and Resource Economics: International Scientific E-Journal

http://are-journal.com

JEL: Q17, Q15, C61

\author{
Vasyl Chemerys, Vitalii Dushka, Mariana Dorosh, Volodymyr Maksym
}

Stepan Gzhytskyi National University of Veterinary Medicine and Biotechnologies Lviv

Ukraine

\title{
EXPORT POTENTIAL OF THE LIVESTOCK BREEDING INDUSTRY OF UKRAINE
}

Purpose. The purpose of the article is to study and substantiate the export potential of the livestock industry of Ukraine based on available resources and taking into account the productivity of fodder crops and farm animals.

Methodology / approach. In the course of the conducted research, general scientific methods were used, in particular, a monographic one at a complex and comprehensive study of production and export potential of livestock products in Ukraine; the calculation-and-design method was used in determining the main options for exporting livestock products by their main types and choosing the best of them; the economic-and-mathematical method was used to optimize the export of livestock products according to the selected criteria of finding the maximum value, taking into account the established technological and market variables.

Results. The article investigates and substantiates the export potential of the livestock industry of Ukraine. Evaluation and planning of fodder resources were carried out that can be used to increase livestock production. An economic-mathematical model was developed to determine the export potential of the livestock industry of Ukraine based on the search for the maximum value of the value of exports, taking into account technological, economic, and market limitations. According to the modeling results, the export potential of the livestock industry of Ukraine, depending on the level of productivity of the resources used, is estimated at 39 to 55.5 bln EUR per year.

Originality / scientific novelty. Modeling method of the optimal structure of livestock production and export of Ukraine was improved taking into account technological, economic, and market factors to ensure the growth of export potential of the industry and efficiency of the use of mobilized resources.

Practical values / implications. The results of the study can be used to justify the development of those areas of livestock in Ukraine, which will ensure maximum efficiency in the distribution of fodder resources from value-added growth, which will contribute to the export potential of livestock and agro-industrial complex in general.

Key words: export potential, livestock products, export modeling of livestock products, export optimization, land use.

Introduction and review of literature. Every year, the world's population increases in the number, and the pressing demand for food, including livestock products, increases more and more. This occurs with a simultaneous reduction in the area of agricultural land suitable for growing plant products and used to provide a fodder base for livestock that will become the biggest challenge for the sustainable development of many overpopulated countries in the world. The productivity of recourse use in plant and livestock breeding in many developed states is approaching 


\section{Agricultural and Resource Economics: International Scientific E-Journal http://are-journal.com}

the biological maximum that can be obtained per unit area of agricultural land or per animal. Accordingly, the potential of such states without attracting additional resources is approaching the limit beyond which it will be more difficult for them to increase agricultural production that would meet the growing world needs. In view of this, an increasing role in meeting the food needs of mankind will be transferred to those countries that have significant resource potential in agriculture, which has not been fully realized yet. One of such countries is Ukraine, which is one of the world's largest exporters of grain, oilseeds, poultry meat and eggs, and has a significant potential for production growth due to one of the world's largest concentrations of black soils.

The works of many economists are devoted to the study of the export potential and development of agriculture of Ukraine, in particular: D. Chalapko, A. Peretiatko, I. Kozak [1], N. Galunets [2], O. Kravchenko [3], A. Kucher [4], V. Lavruk, and O. Lavruk [5], O. Lysak, and L. Andreeva [6], T. Melnyk [7], K. Nakonechna [8], O. Nezdoimynoha [9], N. Patyka [10], V. Rossokha [11], O. Velychko [12], I. Yatsiv [13].

Modeling of the export potential of agriculture in some countries is shown in the works of many foreign scientists: H. Kang [14], O. Ramphul [15], S. Saran, S. Kumar, L. S. Gangwar [16], L. Sugiharti, R. Purwono, M. A. Esquivias Padilla [17], A. Tłuczak [18].

We should also highlight researches of foreign scientists in the economics of agriculture that influenced the formation of our scientific ideas regarding the modeling of export potential of the livestock industry of Ukraine: A. Triantafyllou, G. Dotsis, A. Sarris [19], L. Götz, F. Qiu, J. P. Gervais, T. Glauben [20], Š. Bojnec, I. Fertő, [21]. D. Baiardi, C. Bianchi, E. Lorenzini [22], M. Kilkenny, M. D. Partridge [23]，S. Ferguson，J. Gars [24]， L. Cruz，P. Ramos，E. Barata，A. Sargento [25] S. Wimmer, J. Sauer [26], D. Colman [27], T. T. Assefa [28].

The results of the study on the methodology of automatic identification of the export potential of food products are shown in the works of D. Devyatkin and Y. Otmakhova [29]. There is also research in the international scientific literature on the nonlinear relationships of some economic parameters between grain production and livestock products [30].

However, the issues related to assessing the export potential of Ukraine's livestock section and finding the optimal export structure that will be able to ensure the most efficient use of agricultural resources available to Ukraine through economic modeling remain insufficiently explored.

Agriculture has historically played an important role in the development of Ukraine's economy designed to provide the population with food, to form food security and food independence of the country, but also has a high export potential [10]. Ukraine has significant land and resource potential. Ukraine's land fund is $60.3 \mathrm{mln}$ ha or about $6 \%$ of Europe's territory. Agricultural land accounts for about $19 \%$ of European land, including plough land - about $27 \%$. The structure of agricultural land is shown in figure 1. 
The area of agricultural land per capita is the highest among European countries and is 0.9 hectares of plough land. The total area of agricultural land in Ukraine is $42.7 \mathrm{mln}$ ha or $70 \%$ of the country's territory, and plough land $-32.5 \mathrm{mln}$ ha, or $78.4 \%$ of all agricultural land. Ukraine also has large areas of black soils which are among the most fertile soils in the world. According to the experts' evaluation, their area is from $15.6 \mathrm{mln}$ ha to $17.4 \mathrm{mln}$ ha or about $8 \%$ of world reserves [31]. Agriculture forms more than $17 \%$ of Ukraine's GDP and the export of agricultural products accounts for about $44 \%$ of the country's total exports [34].

In accordance with the Ministry of Agricultural Policy and Food, Ukraine export agricultural products and food to more than 190 countries [32]. Despite the availability of significant resources in agriculture, in 2019 Ukraine exported agricultural products at 20.1 bln EUR [33]. They are mostly grain and industrial crops with a low added cost that are in great demand in the world.

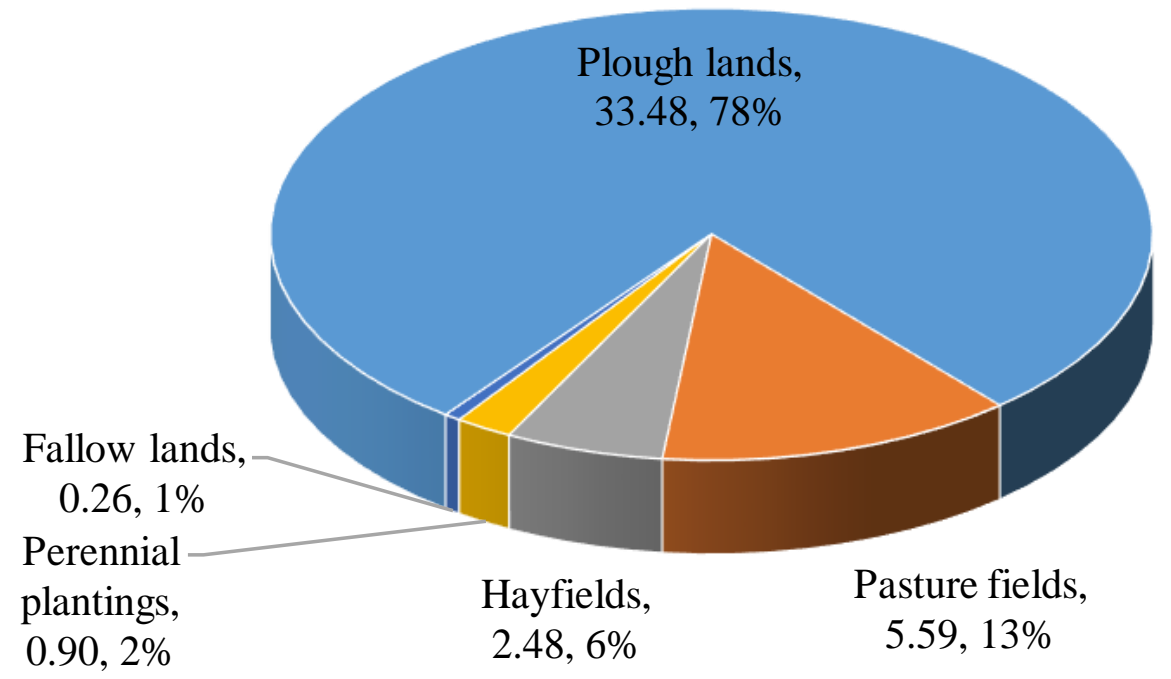

Fig. 1. The structure of agricultural land in Ukraine in 2019

Source: compiled according to the data of State Statistics Service of Ukraine [34].

According to Ukraine's foreign trade, the largest buyers of Ukrainian plant products are the Netherlands, Turkey, Saudi Arabia, Egypt, Germany, Belgium, Spain, Italy, China, and Indonesia. As for livestock products, its largest buyers are Belarus, Kazakhstan, and Arab Emirates [33].

During the years of independence, Ukraine has developed an export-oriented model of economic development, in which the strategic role of export is that it should be a means of promoting economic growth, an instrument to enhance the existing and potential competitive advantages [7].

The Ukrainian agricultural sector with a production potential that greatly exceeds the needs of the domestic market is a link that, in the one hand, can become a locomotive for the national economic development and its effective integration into the world economic space, and on the other hand, the growth of incomes of the rural population involved in the agricultural economy which makes up more than a third of the country's total population, can have a multiplier effect in the development of other national economy sectors [9]. 


\section{Agricultural and Resource Economics: International Scientific E-Journal http://are-journal.com}

An important problem in the development of Ukrainian agriculture is the raw material orientation of product export. Raw material prices are traditionally lower than the cost of finished products of the first or second processing degree. Therefore, to increase export potential, it is necessary to process the raw material into products with a higher level of the added cost, such as meat, milk, eggs, and products of their further processing. This will make it possible to raise the level of profitability per unit of resources involved in agriculture and increase export revenues, which is necessary to support the development of the Ukrainian economy.

It should be emphasized that when using grain for livestock production, the amount of added cost exceeds 5-6 times the income from export operations. For further processing of meat and milk at the food and processing enterprises, there may be an increase in domestic added cost within the country for meat and milk by almost 9 times compared with the export of grain [11]. Accordingly, it is to be noted that by exporting products with a low level of the added cost, Ukraine blocks access to its enterprises for promising sales markets, as it provides raw materials to its competitors in the markets of finished products [35].

The export potential is an integral component of economic potential, which is essentially considered as a volume of goods and services that can be produced in the country and can be realized with maximum benefit for this country [1]. On the one hand, potential - it is available opportunities and resources that are available and used or can be used to achieve a specific goal. On the other hand - these are unused opportunities to increase the efficiency of production or activity [12]. The importance of agricultural export growth as one of the factors for accelerating economic growth, especially developing countries should also be pointed out $[14 ; 15]$.

Accordingly, the urgent task is to determine the export potential of the livestock industry of Ukraine by modeling the optimal structure of production, taking into consideration available resources and various technological and market constraints. This will make it possible to have a more comprehensive assessment of export opportunities and justify the feasibility of structural transformations in the export agri-food policy of Ukraine, which should be aimed at the rational use of limited resources in agriculture with the achievement of high rates of profitability and added cost.

Purpose. The purpose of the article is to study and substantiate the export potential of the livestock industry of Ukraine based on available resources and taking into account the productivity of fodder crops and farm animals.

Methodology. The developed model refers to optimization ones and is aimed at finding the best option for combining livestock production out of the studied species, which will ensure the rational use of limited land and fodder resources in order to ensure domestic consumer needs for food and form the maximum value of export earnings from the sale of surplus livestock products. The maximum value of livestock products export in value terms on a certain resource base will form the export potential of the industry. The model is based on the Excel spreadsheet. The essence of the model development methodology is revealed in the given formulas. In general, 
the simplified objective function of the model can be described by the formula according to which the amount of export revenue for each of the studied types of livestock products should go to the maximum (1):

$$
\sum_{i=1}^{n} V e_{i}+\cdots+V e_{n} \rightarrow \max
$$

where $\mathrm{Ve}_{\mathrm{i}}$ - export price of i-type of livestock products that should go to the maximum.

The extended target function of finding the maximum amount of export of livestock products can be described by the formula (2):

$$
\sum_{i=1}^{n}\left(S_{j} * \frac{U_{j}}{Q_{i y}} * Q l_{i}-Q M_{i}\right) * P e_{i} \rightarrow \max
$$

where $S_{j}$ - planting acreage of j-type of fodder crops, ha;

$U_{j}$ - yield of j-type type of fodder crops, t/ha;

$Q_{j i}$ - demand of j-type of fodder crops for the production of $1 \mathrm{t}$ of $\mathrm{i}$-type of livestock products $\mathrm{t}$;

$Q l_{i}$ - production volume of i-type of livestock products, $\mathrm{t}$;

$P e_{i}$ - export sale price of i-type of livestock products, EUR/t;

$Q M_{i}$ - production volume of i-type of livestock products to meet domestic consumer needs in this type of product, $t$.

To calculate three yield levels, the logical function Excel 'IF' is used, which makes it possible to check whether the set condition is fulfilled and returns one value if it is fulfilled, or it returns another value if the set condition is not fulfilled (3).

$S_{j} * U_{j}=I F\left(T=1 ; U_{j 1} * S_{j} ; 0\right)+I F\left(T=2 ; U_{j 2} * S_{j} ; 0\right)+I F\left(T=3 ; U_{j 3} * S_{j} ; 0\right)$

where $T$ - yield level that takes on value from 1 to 3 ;

$U_{j 1}$ - first yield level (low) of j-type of fodder crops, t/ha;

$U_{j 2}-$ second yield level (middle) of j-type of fodder crops, t/ha;

$U_{j 3}-$ third yield level (high) of j-type of fodder crops, $t / h a$.

Each of the three yield levels has its own indicators for each type of fodder crops that can be used for livestock production.

Variables in the model are the input values of the resources volumes the value of which will be selected in such a way, according to the given restrictions, so that to obtain the maximum number of export from livestock products: $\left(x_{1} \ldots x_{7}\right)$ - livestock production volume, $x_{1}-$ milk, $\mathrm{t} ; x_{2}-$ beef, $\mathrm{t} ; x_{3}-$ pork, $\mathrm{t} ; x_{4}$ - poultry, $\mathrm{t} ; x_{5}-$ lamb and goat meat, $\mathrm{t} ; x_{6}$ - rabbit meat, $\mathrm{t} ; x_{7}-$ eggs, $\mathrm{t} ;\left(x_{8} \ldots x_{18}\right)$ - fodder crop planting acreages, $x_{8}-$ wheat, ha; $x_{9}$ - barley, ha; $x_{10}$ - corn, ha; $x_{11}$ - oats, ha; $x_{12}$ - soybean and protein meal, ha; $x_{13}$ - soybean and cattle cake, ha; $x_{14}$ - sunflower for protein meal, ha; $x_{15}$ - sunflower for cattle cake, ha; $x_{16}$ - roughage fodders, ha; $x_{17}$-green fodders, ha; $x_{18}$ - root crops, ha. The model can select the value of these variables in 
accordance with the set limitations:

$$
\sum_{i=1}^{n} S_{j} \leq 32000000 ; \quad x_{1} \geq 14060000 ; \quad x_{2} \geq 925000 ; \quad x_{3} \geq 925000 ;
$$

$x_{4} \geq 740000 ; x_{5} \geq 185000 ; x_{6} \geq 185000 ; x_{7} \geq 600880$.

The first limitation refers to the value of the area of agricultural land involved, for growing the necessary fodder crops in order to organize the optimal volume of livestock production. The following limitations refer to the minimum volumes of livestock production that must be produced in order to meet the needs of livestock products for the domestic Ukrainian consumer market.

Other limitations according to the formula (4) refer to the appropriateness of agricultural land use on the principle of four-year crop rotation that is the phased alternation of growing crop on one plot of land which has a four-year cycle for more productive land use.

$$
S_{j} \leq \frac{\sum_{j=1}^{n} S_{j}}{4}
$$

The condition for diversification of livestock products export is described by the formula (5) according to which the part of export that will fall on one type of livestock products should not exceed $25 \%$.

$$
V e_{i} \leq \sum_{i=1}^{n}\left(V e_{i}+\cdots+V e_{n}\right) * 0,25
$$

Limitations on the use of fodder resources for livestock production (6) is that the number of fodder resources spent on each of their species for the production of a particular type of livestock products should not exceed the number of fodder resources available.

$$
S_{j} U_{j} \geq \sum_{i=1}^{n} Q_{j i} x_{i}
$$

In the extended form, this limitation can be described by the formula (7) for each type of fodder resources that are foreseen to grow. For instance, the amount of expenses for wheat for growing the planned volume of each of the types of livestock products cannot be higher than the amount of wheat grown on the allotted land.

$$
\begin{aligned}
& S_{1} U_{1} \geq Q_{1} x_{1}+Q_{1} x_{2}+Q_{1} x_{3}+Q_{1} x_{4}+Q_{1} x_{5}+Q_{1} x_{6}+Q_{1} x_{7} \\
& S_{2} U_{2} \geq Q_{2} x_{1}+Q_{2} x_{2}+Q_{2} x_{3}+Q_{2} x_{4}+Q_{2} x_{5}+Q_{2} x_{6}+Q_{2} x_{7} \\
& S_{3} U_{3} \geq Q_{3} x_{1}+Q_{3} x_{2}+Q_{3} x_{3}+Q_{3} x_{4}+Q_{3} x_{5}+Q_{3} x_{6}+Q_{3} x_{7} \\
& S_{4} U_{4} \geq Q_{4} x_{1}+Q_{4} x_{2}+Q_{4} x_{3}+Q_{4} x_{4}+Q_{4} x_{5}+Q_{4} x_{6}+Q_{4} x_{7} \\
& S_{5} U_{5} \geq Q_{5} x_{1}+Q_{5} x_{2}+Q_{5} x_{3}+Q_{5} x_{4}+Q_{5} x_{5}+Q_{5} x_{6}+Q_{5} x_{7} \\
& S_{6} U_{6} \geq Q_{6} x_{1}+Q_{6} x_{2}+Q_{6} x_{3}+Q_{6} x_{4}+Q_{6} x_{5}+Q_{6} x_{6}+Q_{6} x_{7} \\
& S_{7} U_{7} \geq Q_{7} x_{1}+Q_{7} x_{2}+Q_{7} x_{3}+Q_{7} x_{4}+Q_{7} x_{5}+Q_{7} x_{6}+Q_{7} x_{7} \\
& S_{8} U_{8} \geq Q_{8} x_{1}+Q_{8} x_{2}+Q_{8} x_{3}+Q_{8} x_{4}+Q_{8} x_{5}+Q_{8} x_{6}+Q_{8} x_{7} \\
& S_{9} U_{9} \geq Q_{9} x_{1}+Q_{9} x_{2}+Q_{9} x_{3}+Q_{9} x_{4}+Q_{9} x_{5}+Q_{9} x_{6}+Q_{9} x_{7}
\end{aligned}
$$




$$
\begin{aligned}
& S_{10} U_{10} \geq Q_{10} x_{1}+Q_{10} x_{2}+Q_{10} x_{3}+Q_{10} x_{4}+Q_{10} x_{5}+Q_{10} x_{6}+Q_{10} x_{7} \\
& S_{11} U_{11} \geq Q_{11} x_{1}+Q_{11} x_{2}+Q_{11} x_{3}+Q_{11} x_{4}+Q_{11} x_{5}+Q_{11} x_{6}+Q_{11} x_{7}
\end{aligned}
$$

where $S_{1}$ - planting acreage of wheat, ha; $S_{2}$ - planting acreage of barley, ha; $S_{3}$ - planting acreage of corn, ha; $S_{4}$ - planting acreage of oats, ha; $S_{5}$ - planting acreage of soybean for protein meal, ha; $S_{6}$ - planting acreage of soybean for cattle cake, ha; $S_{7}$ - planting acreage of sunflower for protein meal, ha; $S_{8}$ - planting acreage of sunflower for cattle cake, ha; $S_{9}$ - planting acreage of roughage fodders, ha; $S_{10}-$ planting acreage of green fodders, ha; $S_{11}$ - planting acreage of root crops, ha; $U_{1}-$ wheat yield, t/ha; $U_{2}-$ barley yield, t/ha; $U_{3}-$ corn yield, t/ha; $U_{4}-$ oats yield, t/ha; $U_{5}$ - yield of protein meal from 1 ha of soybean harvest, t/ha; $U_{6}$ - yield of cattle cake from 1 ha of soybean harvest, t/ha; $U_{7}$ - yield of protein meal from 1 ha of sunflower harvest, $\mathrm{t} / \mathrm{ha} ; U_{8}$ - yield of cattle cake from 1 ha of sunflower harvest, t/ha; $U_{9}$ - roughage fodders yield, t/ha; $U_{10}-$ green fodders yield, t/ha; $U_{11}$ - root crops yield, t/ha.

The calculation of the planned selling price is carried out according to the formula (8) due to which there is a relationship between the volume of manufactured products and the forecasted price which is characterized by the value of the coefficient of relative change in the price of livestock products with the relative change in the volume of its production compared to world production. That is, an increase in world beef production by $1 \%$ will lead to a decrease in the price of beef by $2 \%$, equal to the value of $E_{i}$.

$$
P e_{i}=P N_{i} * \frac{100-\left(\frac{Q e_{y}}{Q w_{y}} * 100 * E_{i}\right)}{100}
$$

where $P e_{i}$-planned selling price of $1 \mathrm{t}$ of i-type of livestock products, EUR;

$P N_{i}$ - nominal selling price of $1 \mathrm{t}$ of i-type of livestock products, EUR;

$Q e_{i}-$ planned export volume of i-type of livestock products, $\mathrm{t}$;

$Q w_{i}$ - world's production volume of i-type of livestock products, $\mathrm{t}$;

$E_{i}$ - percentage decrease in the sale price of i-type of livestock products with an increase in its export by $1 \%$ (for the model, the value of this indicator is $2 \%$ ).

Limitations on the minimum export price for each of the exported livestock products (9) is that the minimum export price of livestock products cannot be lower than the price level that provides at least $10 \%$ of the profitability of sales in the production of products, subject to the rational use of the resources necessary for its production.

$$
P e_{i} \geq P m_{i}
$$

where $P m_{i}-$ minimum selling price of i-type of livestock products that provides profitability of sales at the level of $10 \%$.

Limitations on export prices for livestock products that cannot be lower than a certain minimum level:

$P e_{1} \geq 260, P e_{2} \geq 2936, P e_{3} \geq 2047, P e_{4} \geq 1360, P e_{5} \geq 3043, P e_{6} \geq 2750, P e_{7} \geq 725$, 
where $P e_{1}$-export price of milk, $P e_{2}$ - of beef, $P e_{3}$ - of pork, $P e_{4}$ - of poultry, $P e_{5}-$ of lamb, $P e_{6}-$ of rabbit meat, $P e_{7}-$ of eggs.

Calculation of the minimum export price is described by the formula (10):

$$
P m_{i}=\frac{C_{i}+T}{1-\frac{R m_{i}}{100}}
$$

where, $C_{i}$ - prime cost of i-type of livestock products;

$\mathrm{Pm}_{i}-$ minimum profitability rate of sales of i-type of livestock products (for the model, the value of this indicator is 10 percent);

$T$ - forecasted income tax amount.

Limitations on the area of agricultural land that can be allocated for the cultivation of fodder crops for the organization of livestock production (11).

$$
\sum_{j=1}^{n} S_{j} \leq(S G-S R) * \frac{(100-(S N+S B))}{100}
$$

where $S G$ - total area of plough land, pasture field, hayfields and fallow lands in Ukraine that can be used for growing crops (except for perennial plantings), ha;

$S R$ - area of agricultural land that must be allocated for the cultivation of crop products when one of the three levels of crop yields is achieved, in sufficient quantities to meet the needs of domestic market;

$S N$ - part of agricultural land necessary for growing seeds of agricultural crops (in the model, the value of the indicator is $10 \%$ );

$S B$ - part of agricultural land that needs to be allocated for reserve production volume of plant products in case of adverse climatic factors (in the model, the value of the indicator is $5 \%$ ).

The area of agricultural land that must be allocated for the cultivation of crop products when one of the three levels of crop yields is achieved, in sufficient quantities to meet the needs of Ukraine domestic market is calculated by the formula (12) using the logical function Excel «IF».

$$
S R=I F\left(T=1 ; \frac{Q A_{j}}{U_{j 1}} ; 0\right)+I F\left(T=2 ; \frac{Q A_{j}}{U_{j 2}} ; 0\right)+I F\left(T=3 ; \frac{Q A_{j}}{U_{j 3}} ; 0\right)
$$

where, $Q A_{j}$ - annual consumption fund of j-type of products in Ukraine.

The use of this technique will allow finding the best option for using input recourses for the livestock production organization in order to achieve the maximum value of export and the most cost-effective structure of livestock production, taking into account the described limitations.

Results and discussion. The export potential of livestock products depends on the volume of its production and level of consumption in the domestic food market. Given this, it is necessary to calculate its potential volumes of production and consumption in order to determine the potential volume of export of livestock products from Ukraine. The difference between them will form the export potential in physical terms. To determine the cost indicator of export, it is also necessary to 


\section{Agricultural and Resource Economics: International Scientific E-Journal http://are-journal.com}

predict the average products' selling price of each type.

The livestock production potential depends to the greatest extent on the available fodder base and efficiency of its use. This will determine the potential number of farm animals that can be bred and kept in Ukraine. In order to calculate the fodder base, it is necessary to take into account the area of agricultural land that can be allocated for the cultivation of the main fodder components used in animal feed, and the potential level of their yield. Also, the level of technological productivity of animals, which in general affects the volume of livestock production, should be taken into consideration.

An important factor influencing the export potential in livestock breeding is the structure of production, which shows the volume and cost of production for each type. In Ukraine, the volume of consumption of livestock products per capita doesn't exceed $50 \mathrm{~kg}$ per year, which is lower than $80 \mathrm{~kg}$ - the norms established by the Ministry of Health of Ukraine. The average salary per month after taxes in Ukraine doesn't exceed 350 EUR. A large part of citizens earns less than 200 EUR per month. The low purchasing power of the population is the main factor of the low level of consumption of meat and dairy products in Ukraine and their replacement by cheaper products such as potatoes, bread, groats, and other plant products. The balance of livestock products in Ukraine is shown in Table 1.

Almost half of all meat consumed is poultry. Poultry is the cheapest and most common type of meat in Ukraine. Retail prices on average do not exceed $2 \mathrm{EUR} / \mathrm{kg}$, and wholesale prices are below 1.5 EUR. More than $95 \%$ of all poultry produced is chicken, which is one of the peculiarities of this market's structure. However, enterprises specializing in the production of other poultry types, in particular duck and turkey meat, enter the market more often nowadays. Beef consumption doesn't exceed $8 \mathrm{~kg}$ per person and it decreases every year. The average retail price for $1 \mathrm{~kg}$ of beef in Ukraine is 5 EUR, which is 2.5 times more expensive than poultry.

Table 1

Balance of meat, meat products, milk, milk products and eggs in Ukraine, thsd. $t$

\begin{tabular}{|c|c|c|c|c|c|c|c|}
\hline \multirow[b]{3}{*}{ Indicator } & \multicolumn{7}{|c|}{2018} \\
\hline & \multirow[b]{2}{*}{ Meat } & \multicolumn{6}{|c|}{ including } \\
\hline & & $\begin{array}{c}\text { Beef } \\
\text { and } \\
\text { veal }\end{array}$ & Pork & $\begin{array}{c}\text { Meat } \\
\text { of } \\
\text { poultry }\end{array}$ & $\begin{array}{c}\text { Other } \\
\text { kinds of } \\
\text { meat }\end{array}$ & $\begin{array}{l}\text { Milk and } \\
\text { milk } \\
\text { products }\end{array}$ & Eggs \\
\hline Production & 2355 & 359 & 703 & 1259 & 34 & 10064 & 932 \\
\hline Stock change (by the end of the year) & -3 & -2 & -3 & 2 & 0 & 74 & -2 \\
\hline Import & 283 & 14 & 128 & 133 & 8 & 180 & 4 \\
\hline Total resources & 2641 & 375 & 834 & 1390 & 42 & 10170 & 938 \\
\hline Export & 399 & 56 & 9 & 330 & 4 & 807 & 186 \\
\hline Spent on fodder, other expenses & 10 & 1 & 4 & 4 & 1 & 1008 & 81 \\
\hline Consumption funds & 2232 & 318 & 821 & 1056 & 37 & 8355 & 671 \\
\hline per capita, $\mathrm{kg}$ & 52.8 & 7.5 & 19.4 & 25.0 & 0.9 & 197.7 & 275 \\
\hline World livestock production, $\mathrm{mln} \mathrm{t}$ & 324.9 & 66.3 & 119.9 & 109.1 & 29.8 & 675.6 & 80.1 \\
\hline
\end{tabular}

Source: compiled according to the data of State Statistics Service of Ukraine [34] and FAO [36]. 
The second place in the meat balance of Ukraine is taken by pork. The level of consumption per person is up to $20 \mathrm{~kg} / \mathrm{year}$, and the average retail price is $3.5 \mathrm{EUR} / \mathrm{kg}$. Consumption of dairy products in terms of milk doesn't exceed $200 \mathrm{~kg}$ per person. This is due to the low level of competition in the dairy market in Ukraine. Processing enterprises buy dairy raw materials at an average price of $0.25 \mathrm{EUR} / \mathrm{kg}$. and sell through a retail network with a high markup of 0.9 EUR/kg. With the development of competition in the milk processing market, the retail price could be halved and amounted, as in Poland for instance, to about $0.5 \mathrm{EUR} / \mathrm{kg}$. Egg consumption in Ukraine is the closest to the norms established by the Ministry of Health and it is 275 eggs per person per year, with an average retail price of 0.65 EUR per 10 pieces.

Ukraine's agriculture is focused on the export of plant products, and the value of exports of livestock products is about $25 \%$ and it is mainly poultry products. The dominance of cheap plant products in the structure of agricultural export is economically unprofitable for Ukraine since the income of the involved resources, in particular agricultural lands, is low. For instance, about 60 quintals of wheat are harvested from 1 hectare of plough land, the export price of which is about 900 EUR, but it is possible to grow 15 quintals of poultry meat on the basis of this grain, the export price of which is 2175 EUR, or get 14 quintals of pork the export price of which is 3010 EUR. According to the focus on livestock production per 1ha of plough land, it is possible to receive more value for the products produced.

The need for export potential modeling lies in the fact that available areas of agricultural land and their potential yield in Ukraine should be taken into account and calculated the optimal structure of various types of export-oriented livestock products on a certain fodder base. The importance of the value of manufactured and exported products, taking into account the established criteria, should be the maximum possible. The modeling process considers the main types of livestock production that are most common in Ukraine: milk, beef, pork, lamb and goat meat, poultry (chicken), rabbit, and wool. For the production of each of these livestock production types, there are established needs for the main fodder types that are most often grown by agricultural enterprises of Ukraine, including wheat, barley, oats, corn, sunflower cattle cake, soybean cattle cake, sunflower protein meal, soybean protein meal, green fodders, roughage fodders, root crops (Table 2).

Table 2

Crop yield levels, $\mathrm{t} / \mathrm{ha}$

\begin{tabular}{|l|c|c|c|}
\hline \multirow{2}{*}{\multicolumn{1}{c|}{ Type of fodder resources }} & \multicolumn{3}{|c|}{ Yield level } \\
\cline { 2 - 4 } & I & II & III \\
\hline Wheat & 6 & 8 & 10 \\
\hline Corn & 8 & 10 & 12 \\
\hline Barley & 4.5 & 5.5 & 6.5 \\
\hline Oats & 3.5 & 4 & 4.5 \\
\hline Soybean protein meal & 1.6 & 1.8 & 2 \\
\hline Soybean cattle cake & 1.5 & 1.7 & 1.9 \\
\hline Sunflower protein meal & 1.2 & 1.3 & 1.4 \\
\hline \hline
\end{tabular}


Agricultural and Resource Economics: International Scientific E-Journal http://are-journal.com

Continuation of table 2

\begin{tabular}{|l|c|c|c|}
\hline Sunflower cattle cake & 1.2 & 1.3 & 1.4 \\
\hline Green fodders & 25 & 30 & 35 \\
\hline Roughage fodders & 7 & 8 & 9 \\
\hline Root crops & 35 & 50 & 65 \\
\hline Potatoes & 25 & 35 & 45 \\
\hline Vegetables & 40 & 50 & 60 \\
\hline Berries & 6 & 8 & 10 \\
\hline Oil & 2 & 2,5 & 3 \\
\hline Fruits & 20 & 25 & 30 \\
\hline Other plant products & 5 & 5.5 & 6 \\
\hline
\end{tabular}

Source: authors' calculations.

The model considers three yield levels for each type of fodder crops that will be used for livestock production. The higher the yield level, the more it is possible to obtain fodder raw materials for livestock production, which will affect the volume of possible export. Accordingly, three results of modeling the export potential will be obtained. There is a determined need for fodder raw material for the production of each of the studied types of livestock products. Table 3 shows the approximate rations for feeding animals, which will provide the planned level of productivity.

Table 3

\section{The structure of costs of certain fodder types for the livestock production, $\%$}

\begin{tabular}{|l|c|c|c|c|c|c|c|c|}
\hline $\begin{array}{c}\text { Resource } \\
\text { component }\end{array}$ & Milk & $\begin{array}{c}\text { Cattle } \\
\text { meat }\end{array}$ & Pork & $\begin{array}{c}\text { Lamb } \\
\text { and goat } \\
\text { meat }\end{array}$ & Poultry & Eggs & $\begin{array}{c}\text { Rabbit } \\
\text { meat }\end{array}$ & $\begin{array}{c}\text { Fodder } \\
\text { nutritional } \\
\text { value, } \\
\text { fodder unit }\end{array}$ \\
\hline Wheat & 4 & 5 & 19 & 2 & 30 & 28 & 0 & 1.27 \\
\hline Corn & 4 & 4 & 20 & 2 & 34 & 34 & 5 & 1.33 \\
\hline Barley & 3 & 4 & 38 & 2 & 9 & 8 & 7 & 1.15 \\
\hline Oats & 3 & 2 & 0 & 5 & 1 & 4 & 12 & 1 \\
\hline Sunflower meal & 0 & 0 & 0 & 2 & 2 & 0 & 0 & 1.03 \\
\hline Soybean meal & 0 & 0 & 10 & 0 & 9 & 9 & 0 & 1.21 \\
\hline Sunflower cake & 2 & 0 & 7 & 0 & 3 & 6 & 2 & 1.08 \\
\hline Soybean cake & 0 & 3 & 0 & 0 & 4 & 2 & 0 & 1.35 \\
\hline Green fodders & 51 & 52 & 0 & 56 & 0 & 0 & 41 & 0.18 \\
\hline $\begin{array}{l}\text { Roughage } \\
\text { fodders }\end{array}$ & 24 & 23 & 0 & 25 & 0 & 0 & 18 & 0.45 \\
\hline $\begin{array}{l}\text { Fodders of } \\
\text { animal origin }\end{array}$ & 0 & 0 & 4 & 0 & 4 & 4 & 0 & 1 \\
\hline $\begin{array}{l}\text { Fodder } \\
\text { additives }\end{array}$ & 2 & 2 & 2 & 2 & 4 & 5 & 2 & 1.1 \\
\hline Root crops & 7 & 5 & 0 & 4 & 0 & 0 & 13 & 0.13 \\
\hline Total & 100 & 100 & 100 & 100 & 100 & 100 & 100 & $\mathrm{X}$ \\
\hline
\end{tabular}

Source: authors' calculations.

Analyzing the above data, it should be noted that the production of milk, beef, and lamb requires more land for growing green and roughage fodders, and to increase the production of poultry meat, eggs, or pork, it is necessary to grow more grain crops and grain legume crops. The structure of feeding diets is an important factor 
that influences the search for the best option in which the value of potential export will be maximum.

Table 4 shows the rates of consumption of fodder resources for livestock production. The calculated volume of fodder consumed depends on the structure of feeding ration, nutritional value of fodder, level of slaughter yield for breeding animals for meat, and on the planned level of animal productivity, which is taken into account in the model. The costs of fodder resources for beef, pork, poultry meat, and lamb are calculated in terms of $1 \mathrm{t}$ of slaughter mass of animals, including the slaughter yield coefficients. The lowest volumes of fodder consumption in physical mass per $1 \mathrm{t}$ of livestock products are achieved in the production of eggs and milk. The largest fodder consumption in the production of lamb is $36.2 \mathrm{t}$. On average, almost $30 \mathrm{t}$ of fodder of different types must be used for the production of $1 \mathrm{t}$ of beef in the slaughter mass.

Table 4 Approximate consumption rates for certain types of fodder per $1 \mathrm{t}$ of milk, eggs, and meat in semi-carcasses, $t$

\begin{tabular}{|l|c|c|c|c|c|c|c|}
\hline \multicolumn{1}{|c|}{ Resource component } & Milk & $\begin{array}{c}\text { Cattle } \\
\text { meat }\end{array}$ & Pork & $\begin{array}{c}\text { Lamb and } \\
\text { goat meat }\end{array}$ & Poultry & Eggs & Rabbit \\
\hline Wheat & 0.095 & 1.458 & 0.668 & 0.725 & 0.982 & 0.567 & 0.000 \\
\hline Corn & 0.095 & 1.167 & 0.703 & 0.725 & 1.112 & 0.688 & 1.098 \\
\hline Barley & 0.071 & 1.167 & 1.337 & 0.725 & 0.294 & 0.162 & 1.537 \\
\hline Oats & 0.071 & 0.583 & 0.000 & 1.813 & 0.033 & 0.081 & 2.634 \\
\hline Sunflower protein meal & 0.000 & 0.000 & 0.000 & 0.725 & 0.065 & 0.000 & 0.000 \\
\hline Soybean protein meal & 0.000 & 0.000 & 0.352 & 0.000 & 0.294 & 0.182 & 0.000 \\
\hline Sunflower cattle cake & 0.048 & 0.000 & 0.246 & 0.000 & 0.098 & 0.121 & 0.439 \\
\hline Soybean cattle cake & 0.000 & 0.875 & 0.000 & 0.000 & 0.131 & 0.040 & 0.000 \\
\hline Green fodders & 1.211 & 15.168 & 0.000 & 20.306 & 0.000 & 0.000 & 9.001 \\
\hline Roughage fodders & 0.570 & 6.709 & 0.000 & 9.065 & 0.000 & 0.000 & 3.952 \\
\hline Fodders of animal origin & 0.000 & 0.000 & 0.141 & 0.000 & 0.131 & 0.081 & 0.000 \\
\hline Fodder additives & 0.048 & 0.583 & 0.070 & 0.725 & 0.131 & 0.101 & 0.439 \\
\hline Root crops & 0.166 & 1.458 & 0.000 & 1.450 & 0.000 & 0.000 & 2.854 \\
\hline Total & 2.375 & 29.169 & 3.517 & 36.260 & 3.272 & 2.023 & 21.954 \\
\hline
\end{tabular}

Source: authors' calculations.

Given the above norms of fodder resource, the model should find such an option for growing fodder components on the available agricultural land areas that are in Ukraine in order to develop the volume of livestock production on their basis so that to meet the needs of the domestic market and export formation the cost of which, including the forecasted market prices, should be maximum.

The modeling results showed that the area of agricultural land that can be allocated for growing fodder crops will increase with the increase of yield. Since the increase in yields reduces the need for the area of land that is necessary to meet the population's domestic needs for food. The total area of agricultural land for livestock needs is estimated from $33.8 \mathrm{mln} / \mathrm{ha}$ at the first level of yield to $34.4 \mathrm{mln} / \mathrm{ha}$ at the third level of yield. This will make it possible to produce from 226 to $321 \mathrm{mln}$ of 
fodder of all types (Table 5).

Table 5

Planting acreages and fodder crops production volume

\begin{tabular}{|l|c|c|c|c|c|c|}
\hline \multicolumn{1}{|c|}{ Fodder type } & $\begin{array}{c}\text { Area, } \\
\text { thsd. ha }\end{array}$ & $\begin{array}{c}\text { Gross yield, } \\
\text { thsd. t } \\
\left(1^{\text {st }} \text { yield }\right. \\
\text { level })\end{array}$ & $\begin{array}{c}\text { Area, } \\
\text { thsd. ha }\end{array}$ & $\begin{array}{c}\text { Gross yield, } \\
\text { thsd. t } \\
\left(2^{\text {nd }} \text { yield }\right. \\
\text { level })\end{array}$ & $\begin{array}{c}\text { Area, } \\
\text { thsd. ha }\end{array}$ & $\begin{array}{c}\text { Gross yield, } \\
\text { thsd. t } \\
\left(3^{\text {rd }} \text { yield }\right. \\
\text { level })\end{array}$ \\
\hline Wheat & 4152 & 24912 & 3644 & 29158 & 3322 & 33227 \\
\hline Barley & 3813 & 17161 & 3753 & 20642 & 3687 & 23970 \\
\hline Corn & 3428 & 27425 & 3151 & 31518 & 2953 & 35439 \\
\hline Oats & 1850 & 6475 & 1847 & 7391 & 1840 & 8283 \\
\hline $\begin{array}{l}\text { Soybean } \\
\text { protein meal }\end{array}$ & 4002 & 6404 & 4009 & 7217 & 3994 & 7988 \\
\hline $\begin{array}{l}\text { Soybean cattle } \\
\text { cake }\end{array}$ & 2129 & 3194 & 2721 & 708 & 3161 & 6006 \\
\hline $\begin{array}{l}\text { Sunflower } \\
\text { protein meal }\end{array}$ & 506 & 607 & 545 & 4625 & 575 & 805 \\
\hline $\begin{array}{l}\text { Sunflower } \\
\text { cattle cake }\end{array}$ & 4718 & 5662 & 4670 & 6072 & 4615 & 6461 \\
\hline $\begin{array}{l}\text { Roughage } \\
\text { fodders }\end{array}$ & 5554 & 38884 & 6047 & 48380 & 6395 & 57559 \\
\hline Green fodders & 3392 & 84802 & 3542 & 106272 & 3629 & 127027 \\
\hline Root crops & 305 & 10690 & 284 & 12789 & 269 & 14824 \\
\hline Total & 33853 & 226221 & 34218 & 274777 & 34444 & 321594 \\
\hline
\end{tabular}

Source: authors' calculations.

In the structure of planting acreage, the largest part will be made up of grains of various types (30-40\%). The area under sunflower will be 35-40\%, and soybean $32-39 \%$. For the roughage fodder production, it is necessary to allocate from 20 to $30 \%$ depending on their yield level. To meet the needs of the domestic market of Ukraine for basic food products in accordance with the recommended Ministry of Health of Ukraine, it is necessary to allocate about $11.6 \mathrm{mln}$ ha of agricultural land when reaching the first level of their productivity, $9.5 \mathrm{mln}$ ha if the second level of land productivity is reached and almost $8.3 \mathrm{mln}$ ha when reaching the third level of productivity (Table 6). In particular, $60 \%$ of the area will be allocated for the production of crop products and about $40 \%$ - for the production of livestock products. In general, it is necessary to produce an average of about $1000 \mathrm{~kg}$ of basic food products per capita per year.

The total food demand is more than $35.5 \mathrm{mln}$ ha, including $17.6 \mathrm{mln}$ of livestock products, and more than 14 mln $\mathrm{t}$ of which are milk and milk products. The data are calculated for $37 \mathrm{mln}$ Ukrainian citizens, according to the population estimate as of December 1, 2019 [37]. Crop production requires almost 20 mln t per year, most of which are vegetables. Increasing the level of productivity of agricultural land use will further promote their more economical use and will reduce the area of land that needs to be allocated to meet domestic consumer needs and through them increase the area of land resources for the formation of export potential in agriculture in general. 


\section{Required area of agricultural land to meet the consumer needs of the Ukrainian} food market

\begin{tabular}{|c|c|c|c|c|c|}
\hline \multirow{3}{*}{ Product type } & \multirow{3}{*}{$\begin{array}{l}\text { Per } \\
\text { capita, } \\
\text { kg }\end{array}$} & \multirow{3}{*}{$\begin{array}{c}\text { Potential } \\
\text { consumption } \\
\text { fund in } \\
\text { Ukraine* }^{*}, \mathrm{t}\end{array}$} & \multirow{2}{*}{\multicolumn{3}{|c|}{$\begin{array}{l}\text { Necessary area of agricultural } \\
\text { land, mln/ha } \\
\text { Land productivity levels }\end{array}$}} \\
\hline & & & & & \\
\hline & & & $1^{\text {st }}$ level & $2^{\text {nd }}$ level & $3^{\text {rd }}$ level \\
\hline Livestock products & 476 & 17620880 & 9037072 & 7485411 & 6619167 \\
\hline Milk and milk products & 380 & 14060000 & 3374400 & 2812000 & 2530800 \\
\hline Cattle meat & 25 & 925000 & 2784250 & 2220000 & 1933250 \\
\hline Pork & 25 & 925000 & 851000 & 721500 & 629000 \\
\hline Poultry & 20 & 740000 & 584600 & 488400 & 429200 \\
\hline Lamb and goat meat & 5 & 185000 & 673400 & 582750 & 514300 \\
\hline Rabbit meat & 5 & 185000 & 481000 & 414400 & 366300 \\
\hline Eggs & 16 & 600880 & 288422 & 246361 & 216317 \\
\hline Plant products & 539 & 19943000 & 2577112 & 2027278 & 1680622 \\
\hline Bread and bread products & 101 & 3737000 & 934250 & 700688 & 560550 \\
\hline Potatoes & 124 & 4588000 & 183520 & 131086 & 101956 \\
\hline Vegetables & 161 & 5957000 & 148925 & 119140 & 99283 \\
\hline Berries & 40 & 1480000 & 246667 & 185000 & 148000 \\
\hline Oil & 13 & 481000 & 601250 & 481000 & 400833 \\
\hline Fruits & 50 & 1850000 & 92500 & 74000 & 61667 \\
\hline Other plant products & 50 & 1850000 & 370000 & 336364 & 308333 \\
\hline Total of crop and livestock products & 1015 & 37563880 & 11614184 & 9512689 & 8299789 \\
\hline
\end{tabular}

Note. *Indicator is calculated according to the recommended consumption norms.

Source: authors' calculations.

According to the results of modeling (Table 7), three options for the livestock production have been identified that will meet the needs of the domestic market in raw materials and form the maximum value of export. Achieving the first level of productivity of growing basic fodder crops will allow obtaining $224 \mathrm{mln} t$ of fodder raw materials on the basis of which it is possible to produce almost $40 \mathrm{mln} t$ of milk, $1.96 \mathrm{mln} t$ of beef, $5.34 \mathrm{mln} \mathrm{t}$ of pork, $0.185 \mathrm{mln} \mathrm{t}$ of lamb and goat meat, more than $7.23 \mathrm{mln} \mathrm{t}$ of poultry meat, $13.15 \mathrm{mln} \mathrm{t}$ of eggs, $0.321 \mathrm{mln} \mathrm{t}$ of rabbit meat and 22 thsd. $t$ of wool.

The forecasted price level for $1 \mathrm{t}$ of sold product is calculated by the formula 8 , will be for milk - 260 EUR, beef - 3135 EUR, pork - 2212 EUR, lamb and goat meat - 3148 EUR, poultry - 1505 EUR, 1 t of eggs - 725 EUR, rabbit meat - 2976 EUR and wool - 2014 EUR. Accordingly, the total cost of livestock production will amount to 50.356 bln EUR.

To meet the needs of the domestic market (of Ukraine) in livestock products according to the standards set by the Ministry of Health of Ukraine, it is necessary to annually supply 14 mln $t$ of milk, 925 thsd. $t$ of beef, 925 thsd. $t$ of pork, 185 thsd. $t$ of lamb and goat meat, 740 thsd. $t$ of poultry meat, more than 600 thsd. t of eggs and about 185 thsd. $t$ of other types of meat. 


\section{Export potential of the livestock industry in Ukraine at different levels of fodder supply}

\begin{tabular}{|c|c|c|c|c|c|c|c|c|}
\hline Indicator & Milk & $\begin{array}{c}\text { Cattle } \\
\text { meat }\end{array}$ & Pork & $\begin{array}{c}\text { Lamb } \\
\text { with wool } \\
\text { and goat } \\
\text { meat }\end{array}$ & Poultry & Eggs & $\begin{array}{c}\text { Rabbit } \\
\text { meat }\end{array}$ & Total \\
\hline $\begin{array}{l}\text { Fodder costs per } 1 \mathrm{t} \\
\text { of products, } \mathrm{t}\end{array}$ & 2.38 & 16.04 & 2.74 & 18.13 & 2.49 & 2.02 & 11.2 & - \\
\hline $\begin{array}{l}\text { in terms of slaughter } \\
\text { weight (for meat), t }\end{array}$ & 2.38 & 29.17 & 3.52 & 36.26 & 3.27 & 2.02 & 21.95 & - \\
\hline $\begin{array}{l}\text { Production volume, } \\
\text { mln t (yield 1) }\end{array}$ & 39.97 & 1.960 & 5.341 & 0.185 & 7.231 & 13.15 & 0.321 & 68.192 \\
\hline $\begin{array}{l}\text { Production volume, } \\
\text { mln t (yield 2) }\end{array}$ & 39.97 & 3.365 & 6.358 & 0.185 & 8.777 & 13.15 & 0.338 & 72.177 \\
\hline $\begin{array}{l}\text { Production volume, } \\
\text { mln t (yield 3) }\end{array}$ & 39.97 & 4.721 & 7.316 & 0.185 & 10.25 & 13.15 & 0.358 & 76.156 \\
\hline $\begin{array}{l}\text { Gross fodder } \\
\text { demand, mln } \mathrm{t} \\
(1 \text { option) }\end{array}$ & 88.30 & 54.30 & 18.787 & 6.439 & 23.66 & 26.62 & 6.144 & 224.26 \\
\hline (2 option) & 88.30 & 93.24 & 22.363 & 6.439 & 28.71 & 26.62 & 6.474 & 272.16 \\
\hline (3 option) & 88.30 & 130.8 & 25.732 & 6.439 & 33.55 & 26.62 & 6.846 & 318.33 \\
\hline $\begin{array}{l}\text { Product price, EUR/t } \\
\text { ( } 1 \text { option })\end{array}$ & 260 & 3135 & 2212 & 3148 & 1505 & 725 & 2976 & - \\
\hline$(2$ option)) & 260 & 3068 & 192 & 3148 & 1482 & 725 & 2937 & - \\
\hline (3 option)) & 260 & 3003 & 174 & 3148 & 1460 & 725 & 2894 & - \\
\hline $\begin{array}{l}\text { Cost of manufactured } \\
\text { products, bln EUR } \\
\text { (1 option) }\end{array}$ & 10.39 & 6.145 & 11.814 & 0.582 & 10.88 & 9.538 & 0.956 & 50.356 \\
\hline ( 2 option) & 10.39 & 10.32 & 13.939 & 0.582 & 13.00 & 9.538 & .995 & 58.825 \\
\hline (3 option) & 10.39 & 14.17 & 15.905 & 0.582 & 14.97 & 9.538 & .037 & 66.653 \\
\hline $\begin{array}{l}\text { Domestic } \\
\text { consumption, mln } \mathrm{t}\end{array}$ & 14.06 & 0.925 & 0.925 & 0.185 & 0.740 & 0.601 & 0.185 & 17.620 \\
\hline Export volume, mln $\mathrm{t}$ & 25.91 & 1.035 & 4.416 & 0 & 6.491 & 12.55 & .136 & 50.548 \\
\hline (2 option) & 25.91 & 2.440 & 5.433 & 0 & 8.037 & 12.55 & 0.154 & 54.534 \\
\hline (3 option) & 25.91 & 3.796 & 6.391 & 0 & 9.513 & 12.55 & 0.173 & 58.344 \\
\hline $\begin{array}{l}\text { Export revenue, bln } \\
\text { EUR ( } 1 \text { option) }\end{array}$ & 6.738 & 3.245 & 9.768 & 0 & 9.768 & 9.102 & 0.406 & 39.027 \\
\hline (2 option) & 6.738 & 7.486 & 11.911 & 0 & 11.91 & 9.102 & 0.452 & 47.601 \\
\hline (3 option) & 6.738 & 11.40 & 13.894 & 0 & 13.89 & 9.102 & 0.502 & 55.530 \\
\hline
\end{tabular}

Source: authors' calculations.

Accordingly, the export potential in physical terms will be calculated as the difference between the maximum possible volume of livestock production, taking into account the limitations set in the volume of consumption of these products in the domestic market. Given this, the possible annual export of milk will amount to $25.91 \mathrm{mln} t$ worth 6.7 bln EUR, beef - 1.03 mln t worth 3.24 bln EUR. The largest export volumes are pork $4.41 \mathrm{mln}$ t worth up to $10 \mathrm{bln}$ EUR and poultry meat 
$6.49 \mathrm{mln} t$ the estimated export price of which will be such as pork.

Also, significant export volumes under the first option will be eggs, $12.5 \mathrm{mln} t$, the export price of which will be more than 9.1 bln EUR. The export price of 136.3 thsd. $t$ of rabbit meat will reach 405.7 mln EUR. The results of modeling showed that considering the set limitations and input data, it is most advisable to concentrate resources primarily on the production and further export of pork, poultry meat and eggs since the production of these types of livestock products achieves the highest export price per each unit of mobilized fodder resources, and per each unit of the agricultural land area involved in the production of necessary fodders.

The least efficient, considering the principle of efficient allocation of raw materials, is lamb and goat meat production, which is why the production volume is equal to the set limit of 185 thsd. $t$ which are necessary to ensure the domestic consumer market for this livestock product. It is worth noting that an important factor that affects a certain optimal level of production is the elasticity of product prices under the influence of changes in market supply. That is, there is a certain limit to which the model can offer to increase the production volume of a promising type of product, the intersection, and increasing distance from which makes the production of this type of product less effective, or not appropriate at all.

Since an increase in production volume with unchanged consumption volumes leads to lower market prices that affect the profitability of such production and reduce the potential export value. That is why the model selects such a production volume at which the price will provide the maximum export amount. The total export revenue from the sale of a certain volume of livestock products upon reaching the first option for the productivity of fodder crops can potentially be 39.07 bln EUR per year that is 24 bln EUR more than the value of all exported agricultural products of Ukraine in 2019.

Reaching the second level of productivity of growing basic fodder crops will allow obtaining $272 \mathrm{mln}$ t of fodder raw materials that is $21.4 \%$ more than in the first option. In terms of the obtained food base, according to the modeling results, it is proposed to produce $3.36 \mathrm{mln}$ t of beef, $6.35 \mathrm{mln} \mathrm{t}$ of pork, more than $8.77 \mathrm{mln} \mathrm{t}$ of poultry meat, $0.339 \mathrm{mln} \mathrm{t}$ of rabbit meat. The level of prices for the sale and production of milk, lamb and goat meat, eggs, and wool is the same as in the first option.

The projected price level will decrease for beef, pork, and poultry and rabbit meat due to the growth of their production. The total value of livestock products will be 58.825 bln EUR and potential export will increase by $22 \%$ compared with the first option and will amount to 47.64 bln EUR per year, which is twice the value of agricultural export to Ukraine in 2019. Reaching the highest level of productivity of basic fodder crops that is typical for the third modeling option, will make it possible to obtain more than $318 \mathrm{mln} \mathrm{t}$ of fodder, which is $42 \%$ more than the first option and $16,9 \%$ more than in the second option. Increasing the productivity of attracted agricultural land will create opportunities for the growth of the export potential of livestock products at 55.6 bln EUR per year, which is three times more than the 
current export potential of agriculture in Ukraine, mainly focused on the sale of grain and oil crops. Production volumes and milk export will amount to both the first and second options, but the production of most other livestock products will increase.

To ensure the highest export value, taking into consideration limitations as for export diversification, namely, the condition under which the part of export for one type of livestock products should not exceed $25 \%$ of the total value, and based on the modeling results, the optimal combination of production volumes for each of the studied types of livestock products is obtained. In particular, beef production is proposed at the level of $4.72 \mathrm{mln} t$, pork $-7.32 \mathrm{mln} t$, poultry meat $-10.25 \mathrm{mln} \mathrm{t}$, eggs $-13.15 \mathrm{mln} \mathrm{t}$, rabbit meat -358.4 thsd. t.

The defined optimal production volumes will make it possible to meet the needs of the domestic consumer market for livestock products and generate significant export potential, including beef at the level of 11.4 bln EUR, pork, and poultry meat at the level up to 13.89 bln EUR, rabbit meat -0.5 bln EUR. Thus, half of the entire export will be pork and poultry, $20.5 \%$ - beef, eggs $-16.4 \%$, milk $-12.1 \%$, and approximately $1 \%$ - rabbit meat and wool. The projected selling price which is affected by the volume of product supply in the market cannot be lower than the minimum allowable price, which is attractive to the business. The marginal price level should provide at least $10 \%$ of sales profitability in the Ukrainian economy with the rational use of material, technical and labor resources necessary for the production organization (Table 8).

Table 8

Minimum price of livestock products export

\begin{tabular}{|l|c|c|c|c|c|c|c|}
\hline \multicolumn{1}{|c|}{ Indicator } & Milk & Beef & Pork & $\begin{array}{c}\text { Lamb with } \\
\text { wool and } \\
\text { goat meat }\end{array}$ & Poultry & Eggs & $\begin{array}{c}\text { Rabbit } \\
\text { meat }\end{array}$ \\
\hline $\begin{array}{l}\text { Minimum export price, } \\
\text { EUR/t }\end{array}$ & 260 & 2936 & 2047 & 3043 & 1360 & 725 & 2750 \\
\hline Prime cost, EUR/t & 227.9 & 2573.4 & 1795.7 & 2670.0 & 1194.0 & 636.6 & 2413.3 \\
\hline $\begin{array}{l}\text { Income tax (18\%), } \\
\text { EUR/t }\end{array}$ & 5.8 & 65.3 & 45.2 & 67.1 & 29.9 & 15.9 & 60.6 \\
\hline $\begin{array}{l}\text { After-tax income at the } \\
\text { minimum export price, } \\
\text { EUR/t }\end{array}$ & 26.3 & 297.3 & 206.1 & 305.9 & 136.1 & 72.5 & 276.1 \\
\hline $\begin{array}{l}\text { Profitability of sales at } \\
\text { the minim export price, } \\
\%\end{array}$ & 10.12 & 10.13 & 10.07 & 10.05 & 10.01 & 10.00 & 10.04 \\
\hline
\end{tabular}

Source: authors' calculations.

To determine the marginal level of the selling price, the average industry indicator of the prime cost of each of the studied types of livestock products can be achieved with the rational use of resources involved. Based on the calculated prime cost level and taking into account the limitations on the level of profitability of sales, the maximum price level in Ukraine for milk should be at least $260 \mathrm{EUR} / \mathrm{t}$, poultry meat -1360 EUR/t, rabbit meat -2750 EUR/t, eggs -725 EUR/t. The highest level of the marginal price is for lamb and goat meat - more than $3000 \mathrm{EUR} / \mathrm{t}$, which is 
entailed with the relatively high cost of production of these livestock products. Accordingly, the model will select the value of production volume the volume of which will not be able to reduce the export price below the limit set for each type of livestock product that is fixed in the limitations.

The level of productivity affects the possible volume of production, the value of which will affect the projected level of export prices, and the higher it is, the lower the export price will be and vice versa. Therefore, one of the tasks of the model is to find a balance between the amount that can be produced on the obtained fodder base at a certain level of productivity and the projected export price that should not be lower than the marginal, minimum price that forms the economic interest of enterprises to produce livestock products. Since the violation of this balance will reduce the investment attractiveness of such business and may lead to the withdrawal of some manufacturers from the market. According to the modeling results, which are shown in table 9, the profitability of sales was determined at the projected export price for various types of livestock products.

Table 9

Profitability of sales at the forecasted export price

\begin{tabular}{|c|c|c|c|c|c|c|c|}
\hline Indicator & Milk & Beef & Pork & $\begin{array}{l}\text { Lamb with } \\
\text { wool and } \\
\text { goat meat }\end{array}$ & Poultry & Eggs & $\begin{array}{c}\text { Rabbit } \\
\text { meat }\end{array}$ \\
\hline \multicolumn{8}{|c|}{1 level of productivity } \\
\hline $\begin{array}{l}\text { Profitability of } \\
\text { sales, } \%\end{array}$ & 10.12 & 17.91 & 18.82 & 15.18 & 20.66 & 12.20 & 18.91 \\
\hline Price, EUR/t & 260 & 3135 & 2212 & 3148 & 1505 & 725 & 2976 \\
\hline \multicolumn{8}{|c|}{2 level of productivity } \\
\hline $\begin{array}{l}\text { Profitability of } \\
\text { sales, } \%\end{array}$ & 10.12 & 16.12 & 18.08 & 15.18 & 19.43 & 12.20 & 17.83 \\
\hline Price, EUR/t & 260 & 3068 & 2192 & 3148 & 1482 & 725 & 2937 \\
\hline \multicolumn{8}{|c|}{3 level of productivity } \\
\hline $\begin{array}{l}\text { Profitability of } \\
\text { sales, } \%\end{array}$ & 10.12 & 14.30 & 17.40 & 15.18 & 18.22 & 12.20 & 16.61 \\
\hline Price, EUR/t & 260 & 3003 & 2174 & 3148 & 1460 & 725 & 2894 \\
\hline
\end{tabular}

Source: authors' calculations.

For milk, the projected export price is equal to minimum and is $260 \mathrm{EUR} / \mathrm{t}$. Beef production at a selling price of 3000-3135 EUR/t, depending on production volumes, will allow manufacturers to receive from 14.3 to $18 \%$ of sales profitability. The projected prices of pork and rabbit meat will make it possible to get 16-18\% profitability of sales, and eggs - about $12 \%$. The highest profitability is projected for poultry meat manufacturers $-18-21 \%$ due to the relatively significant difference of 100-150 EUR per ton between the projected export price and the minimum acceptable. The balance found between production volumes and projected export prices, to our thinking, will stimulate the development of livestock in Ukraine and will promote the realization of the export potential of the industry.

To calculate the production potential of livestock products, the model contains basic norms of fodder consumption for the production of each of the studied types of 
livestock products, as well as animal productivity. The level of animal productivity affects the volume of production, as well as the number of animals that must be kept to ensure a certain level of production defined in the model. According to the results of the study, it is estimated that for the production of $39 \mathrm{mln} \mathrm{t}$ of milk, it is necessary to keep about $6,6 \mathrm{mln}$ of cows. For the production of $2-5 \mathrm{mln}$ t of beef, it is required from 5,6 to $13,5 \mathrm{mln}$ of heads of cattle, depending on the available fodder base (Table 10).

Table 10

Number of animals required to ensure a certain level of export potential

\begin{tabular}{|l|c|c|c|c|c|c|c|}
\hline \multicolumn{1}{|c|}{ Indicator } & Milk & $\begin{array}{c}\text { Cattle } \\
\text { meat }\end{array}$ & Pork & $\begin{array}{c}\text { Lamb } \\
\text { and goat } \\
\text { meat }\end{array}$ & Poultry & Eggs & $\begin{array}{c}\text { Other } \\
\text { types of } \\
\text { meat }\end{array}$ \\
\hline $\begin{array}{l}\text { Production productivity per } \\
\text { year per 1 head, t }\end{array}$ & 6 & 0.35 & 0.085 & 0.025 & 0.0025 & 0.01596 & 0.003 \\
\hline Slaughter yield coefficient & 1 & 0.55 & 0.78 & 0.5 & 0.76 & 1 & 0.51 \\
\hline $\begin{array}{l}\text { Fodder costs per 1 t of } \\
\text { product, t }\end{array}$ & 1 & 7.2 & 3.3 & 7 & 3.1 & 2.5 & 5.4 \\
\hline \multicolumn{7}{|c|}{ Average annual number of animals, mln of heads } \\
\hline 1 level of land productivity & 6.5 & 5.60 & 31.42 & 7.40 & 413.22 & 824.33 & 53.55 \\
\hline 2 level of land productivity & 6.5 & 9.61 & 37.40 & 7.40 & 501.54 & 824.33 & 56.49 \\
\hline 3 level of land productivity & 6.5 & 13.49 & 43.03 & 7.40 & 585.92 & 824.33 & 59.74 \\
\hline \multicolumn{7}{|c|}{ Production of livestock products per capita, t } \\
\hline 1 level of land productivity & 1.080 & 0.053 & 0.144 & 0.005 & 0.195 & 0.356 & 0.009 \\
\hline 2 level of land productivity & 1.080 & 0.091 & 0.172 & 0.005 & 0.237 & 0.356 & 0.009 \\
\hline 3 level of land productivity & 1.080 & 0.128 & 0.198 & 0.005 & 0.277 & 0.356 & 0.010 \\
\hline
\end{tabular}

Source: authors' calculations.

The highest profitability per 1 ha of mobilized land resources (Table 11) is achieved in the production of pork. Depending on the level of the yield of fodder crops and the projected level of selling prices, it is possible to receive from 2.5 to 3.4 thsd. EUR/ha. The second place in terms of profitability per 1 ha is occupied by chicken meat from 2 to 2.8 thsd. EUR/ha. Egg production gives from 1.8 to 2.4 thsd. EUR/ha at the first yield level, when the second level of fodder crop yield is reached. The lowest rates of return per 1 ha of mobilized land resources are achieved in the production of lamb and cattle meat that is associated with a significant expenditure of fodder resources for breeding these animals and relatively low slaughter yield of meat which usually doesn't exceed $55 \%$.

Table 11

Product price per 1 ha of agricultural land, EUR

\begin{tabular}{|c|c|c|c|c|c|c|c|}
\hline $\begin{array}{c}\text { Productivity } \\
\text { level }\end{array}$ & Milk & $\begin{array}{c}\text { Cattle } \\
\text { meat }\end{array}$ & Pork & $\begin{array}{c}\text { Lamb with } \\
\text { wool and } \\
\text { goat meat }\end{array}$ & Poultry & Eggs & $\begin{array}{c}\text { Rabbit } \\
\text { meat }\end{array}$ \\
\hline 1 & 1159.0 & 1074.8 & 2511.7 & 941.5 & 2051.8 & 1799.0 & 1416.2 \\
\hline 2 & 1352.8 & 1344.3 & 2960.4 & 1089.6 & 2432.9 & 2124.9 & 1643.7 \\
\hline 3 & 1540.8 & 1546.5 & 3389.1 & 1234.4 & 2794.5 & 2433.6 & 1866.7 \\
\hline
\end{tabular}

Source: authors' calculations.

The calculated profitability indicators per unit area of agricultural land used for 


\section{Agricultural and Resource Economics: International Scientific E-Journal http://are-journal.com}

growing fodder crops also depends on indicators of technological production efficiency, in particular, they include milk yield per cow per year, meat production in slaughter mass per 1 head of pigs, cattle meat, sheep, poultry, rabbits, egg yield, as well as the average fodder consumption in fodder units per $1 \mathrm{t}$ of livestock production. Accordingly, the model primarily selects options for the livestock production with the highest level of profitability per unit area, taking into account the established limitations, and options for the production of products with the lower level of profitability will be considered further, but with the condition that sufficient fodder resources will remain for them.

Table 12

Land area for the production of $1 \mathrm{t}$ of livestock products, ha

\begin{tabular}{|c|c|c|c|c|c|c|c|}
\hline Productivity level & Milk & $\begin{array}{c}\text { Cattle } \\
\text { meat }\end{array}$ & Pork & $\begin{array}{c}\text { Lamb with } \\
\text { wool and } \\
\text { goat meat }\end{array}$ & Poultry & Eggs & $\begin{array}{c}\text { Rabbit } \\
\text { meat }\end{array}$ \\
\hline 1 & 0.24 & 3.01 & 0.92 & 3.64 & 0.79 & 0.48 & 2.60 \\
\hline 2 & 0.20 & 2.40 & 0.78 & 3.15 & 0.66 & 0.41 & 2.24 \\
\hline 3 & 0.18 & 2.09 & 0.68 & 2.78 & 0.58 & 0.36 & 1.98 \\
\hline
\end{tabular}

Source: authors' calculations.

The production of $1 \mathrm{t}$ of milk requires from 0.18 to 0.24 ha of land on which fodder crops will be grown (Table 12). This is the lowest rate amongst the studied types of livestock products. Most of the land resources must be allocated in the production of lamb from 2.78 to 3.64 ha per $1 \mathrm{t}$ of production, depending on the level of the yield of fodder crops. The production of beef is also resource-intensive, and for each ton of which it is required from 2.09 to 3.01 ha of agricultural land. The production of $1 \mathrm{t}$ of eggs requires up to 0.5 ha of agricultural land. For the production of $1 \mathrm{t}$ of chicken meat, it is necessary only from 0.36 ha at the third yield level to 0.48 ha, if the first yield level set in the model is reached. This is 4 times less than in the production of lamb and $15 \%$ less than in the production of pork. The production of rabbit meat requires fewer land resources than beef of lamb production, but 2.5 to 3 times more than pork and poultry production. The level of animal productivity and yield are two most important factors that affect the area of crops that need to be involved to provide fodder for livestock production.

Conclusions. To assess the export potential of livestock in Ukraine, the optimization model has been developed, with the help of which the maximum value of export of livestock products is determined, taking into account various technological and market limitations. The modeling results showed that the export potential of Ukraine's agriculture can be scaled up massively by changing the orientation of agricultural production from the crop direction of specialization to livestock one. Since the production of livestock products reaches a higher level of added value than the production of most types of crop products that are exported for further processing to other countries.

Most areas of agricultural land in Ukraine are allocated for the production of cheap plant raw materials, the performance efficiency of which is low. However, if 
these resources are directed to the cultivation of fodder crops for livestock production, it is possible to achieve much higher indicators of the effectiveness of the distribution of mobilized land resources. For instance, the results of the study showed that 1 ha of agricultural land used to organize the production of milk makes it possible to maximize revenue up to 1540 EUR, pork production - 3390 EUR, poultry - 2800 EUR, eggs - more than 2400 EUR. On the other hand, when growing grain or sunflower for export, the income per unit area of land will be 3-4 times lower. Thereby, to increase the value of agricultural export, it is necessary to develop those types of products in which it is possible to achieve a higher level of added value, receiving higher income per unit of involved logistical and land resources.

Based on the modeling results, it was calculated that the export potential of livestock breeding in Ukraine may range from 39 to 55.5 bln EUR, depending on the achieved level of fodder supply that is affected by the level of the yield of fodder crops which are proposed to be grown and taking into account various limitations, in particular, such as the minim export price, which allows enterprises to get profitability of sales of at least $10 \%$, limitations on export diversification, coefficient of price elasticity from changes in the supply of products on the market, limitations on accounting from crop rotation fodder expenses for the production of each of the studied types of livestock products, yield level of the main fodder crops, limitations on meeting the needs of the domestic market of Ukraine for basic food products and others. Accordingly, the modeling results will differ when the set limitations are changed. A promising area of further researches is the development of optimization models in the plant industry that will allow establishing a rational structure of production and product export including various technological, economic, market factors so that to reach a higher level of economic efficiency of the use of agricultural land of Ukraine.

\section{References}

1. Chalapko, D., Peretiatko, A. and Kozak, I. (2016), Export potential of Ukraine: problems and prospects of realization. Scientific Bulletin of National Forestry University of Ukraine, vol. 2, no. 26, pp. 247-253. https://doi.org/10.15421/40260237.

2. Galunets, N. (2019), Place of the Ukrainian agricultural exports on the world food market. Agricultural and Resource Economics, vol. 5, no. 4, pp. 79-94, available at: https://are-journal.com.

3. Kravchenko, O. (2019), Special aspects of economic relations between participants of the market for livestock products. Agricultural and Resource Economics, vol. 5, no. 1, pp. 71-91, available at: https://are-journal.com.

4. Kucher, A. (2020), Soil fertility, financial support, and sustainable competitiveness: evidence from Ukraine. Agricultural and Resource Economics, vol. 6, no. 2, pp. 5-23, available at: https://are-journal.com.

5. Lavruk, V. and Lavruk, O. (2019), Methodology of research of the process of economic modernization and development of livestock industry under conditions of deficit of financial resources. Agricultural and Resource Economics, vol. 5, no. 4, 
pp. 137-155, available at: https://are-journal.com.

6. Lysak, O. and Andreeva, L. (2017), Problems and prospects of Ukraine's export of agricultural products. Agricultural and Resource Economics, vol. 3, no. 1, pp. 139-151, available at: https://are-journal.com.

7. Melnyk, T. (2008), Ukraine's export potential: evaluation methodology and analysis. International Economic Policy, no. 1-2, pp. 241-271.

8. Nakonechna, K. (2019), Export potential of agricultural products of Ukraine: perspectives of development. Efektyvna ekonomika, vol. 10, available at: http://www.economy.nayka.com.ua/?op=1\&z=7329.

9. Nezdoimynoha, O. (2017), Development of agricultural export in Ukraine. Economy and society, no. 13, pp. 108-112.

10. Patyka, N. (2019), Directions and prospects for the integration of Ukraine's agriculture in the global agricultural market. Scientific Bulletin of Uzhhorod National University, vol. 23, no. 2, pp. 53-60.

11. Rossokha, V. (2009), Associations as a factor in the socio-economic development of society. Bulletin of the National Pedagogical University named after Ivan Ohiienko. Economic sciences, no. 2, pp. 247-252.

12. Velychko, O. (2015), The essence of enterprise economic potential. Actuasl problems of economics, no. 9(171), pp. 15-20.

13. Yatsiv, I. (2016), The formation of the animal products export by Ukrainian enterprises. Agrosvit, vol. 15-16, pp. 3-8.

14. Kang, H. (2015), Agricultural exports and economic growth: empirical evidence from the major rice exporting countries. Agricultural Economics - Czech, vol. 61, pp. 81-87. https://doi.org/10.17221/99/2014-AGRICECON.

15. Ramphul, O. (2013), Agricultural exports and the growth of agriculture in India. Agricultural Economics - Czech, vol. 59, pp. 211-218. https://doi.org/10.17221/118/2012-AGRICECON.

16. Saran, S., Kumar, S. and Gangwar, L. S. (2013), India's exports performance in poultry products and the potential exports destinations. Agricultural Economics Czech, vol. 59, pp. 134-142. https://doi.org/10.17221/106/2012-AGRICECON.

17. Sugiharti, L., Purwono, R. and Esquivias Padilla, M. A. (2020), Analysis of determinants of Indonesian agricultural exports. Entrepreneurship and Sustainability Issues 7(4): 2676-2695. https://doi.org/10.9770/jesi.2020.7.4(8).

18. Tłuczak, A. (2019), Potential and competitiveness of EU countries in terms of slaughter livestock production. Agricultural Economics - Czech, vol. 65, pp. 550559. https://doi.org/10.17221/156/2019-AGRICECON.

19. Triantafyllou, A., Dotsis, G. and Sarris, A. (2020), Assessing the vulnerability to price spikes in agricultural commodity markets. Journal of Agricultural Economics, vol. 71, no. 3, pp. 631-651. https://doi.org/10.1111/14779552.12377.

20. Götz, L., Qiu, F., Gervais, J. P. and Glauben, T. (2016), Export restrictions and smooth transition cointegration: export quotas for wheat in Ukraine. Journal of Agricultural Economics, vol. 67, is. 2, pp. 398-419. https://doi.org/10.1111/1477- 
9552.12149.

21. Bojnec, Š. and Fertő, I. (2017), Quality upgrades of EU agri-food exports. Journal of Agricultural Economics, vol. 68, is. 1, pp. 269-279. https://doi.org/10.1111/1477-9552.12204.

22. Baiardi, D., Bianchi, C. and Lorenzini, E. (2015), Food competition in world markets: some evidence from a panel data analysis of top exporting countries. Journal of Agricultural Economics, vol. 66, is. 2, pp. 358-391. https://doi.org/10.1111/1477-9552.12094.

23. Kilkenny, M. and Partridge, M. D. (2009), Export sectors and rural development. American Journal of Agricultural Economics, vol. 91, is. 4, pp. 910 929. https://doi.org/10.1111/j.1467-8276.2009.01320.x.

24. Ferguson, S. and Gars, J. (2020), Measuring the impact of agricultural production shocks on international trade flows. European Review of Agricultural Economics, vol. 47, is. 3, pp. 1094-1132. https://doi.org/10.1093/erae/jbz013.

25. Cruz, L., Ramos, P., Barata, E. and Sargento, A. (2017), Assessing an agrifood development strategy: a bi-regional input-output model with resourceconstrained sectors. European Review of Agricultural Economics, vol. 44, is. 5, pp. 860-882. https://doi.org/10.1093/erae/jbw028.

26. Wimmer, S. and Sauer, J. (2020), Diversification economies in dairy farming - empirical evidence from Germany. European Review of Agricultural Economics, vol. 47, is. 3, pp. 1338-1365. https://doi.org/10.1093/erae/jbaa001.

27. Colman, D. (2013), Productivity growth in agriculture: an international perspective. European Review of Agricultural Economics, vol. 40, is. 3, pp. 531-534. https://doi.org/10.1093/erae/jbt013.

28. Assefa, T. T. (2015), Agricultural product prices. European Review of Agricultural Economics, vol. 42, is. 1, pp. 179-182, https://doi.org/10.1093/erae/jbu035.

29. Devyatkin, D. and Otmakhova, Y. (2020), Methodology for automated identifying food export potential in Data Analytics and Management in Data Intensive Domains. DAMDID/RCDL 2019. Communications in Computer and Information Science, eds A. Elizarov, B. Novikov, S. Stupnikov, vol. 1223. Springer, Cham, Switzerland. https://doi.org/10.1007/978-3-030-51913-1_2.

30. Fiszeder, P. and Orzeszko, W. (2018), Nonlinear granger causality between grains and livestock. Agricultural Economics - Czech, vol. 64, pp. 328-336. https://doi.org/10.17221/376/2016-AGRICECON.

31. Strategy for improving the management mechanism in the field of use and protection of state-owned agricultural lands and their disposal (2017), available at: https://zakon.rada.gov.ua/laws/show/413-2017-ח.

32. The official site of Ministry for Development of Economy, Trade and Agriculture of Ukraine (2020), available at: https://www.me.gov.ua/?lang=uk-UA.

33. Ukraine's foreign trade, indicating the main countries-counterparties (2019), available at: http://sfs.gov.ua/ms/f3.

34. The official site of State Statistics Service of Ukraine, available at: 
http://www.ukrstat.gov.ua.

35. Kovalchuk, M. (2006), Export potential of Ukraine: problems of realization and ways of improvement, available at: http://ena.lp.edu.ua:8080/bitstream/ntb/36043/1/51_300-304.pdf.

36. Faostat (2018), Livestock Primary, available at: http://www.fao.org.

37. Dubilet, D. (2020), Estimation of the current population of Ukraine, available at: https://www.kmu.gov.ua/mediagallery/brifing-ministra-kabinetuministriv-dmitra-dubileta.

How to cite this article? Як цитувати цю статтю?

Стиль - ДСТУ:

Chemerys V., Dushka V., Dorosh M., Maksym V. Export potential of the livestock breeding industry of Ukraine. Agricultural and Resource Economics. 2020. Vol. 6. No. 3. Pp. 5-28. URL: http://are-journal.com.

Style - Harvard:

Chemerys, V., Dushka, V., Dorosh, M. and Maksym, V. (2020), Export potential of the livestock breeding industry of Ukraine. Agricultural and Resource Economics, vol. 6, no. 3, pp. 5-28, available at: http://are-journal.com. 